\title{
White-Collar Proletariat
}




\section{Also by Rosemary Crompton}

Dorothy Wedderburn and Rosemary Crompton, Workers' Attitudes and Technology

Rosemary Crompton and Jon Gubbay, Economy and Class Structure 


\title{
White-Collar Proletariat
}

\section{Deskilling and Gender in Clerical Work}

\author{
Rosemary Crompton \\ and \\ Gareth Jones
}

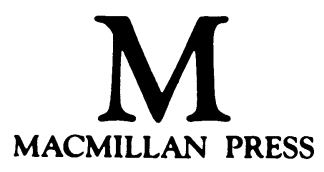


단 Rosemary Crompton and Gareth Jones 1984

All rights reserved. No reproduction, copy or transmission of this publication may be made without written permission.

No paragraph of this publication may be reproduced, copied or transmitted save with written permission or in accordance with the provisions of the Copyright Act 1956 (as amended).

Any person who does any unauthorised act in relation to this publication may be liable to criminal prosecution and civil claims for damages.

First published 1984

Reprinted 1986

Published by

MACMILLAN EDUCATION LTD

Houndmills, Basingstoke, Hampshire RG21 2XS

and London

Companies and representatives

throughout the world

British Library Cataloguing in Publication Data

Crompton, Rosemary

White-collar proletariat.

1. White collar workers

I. Title II. Jones, Gareth

306'.36 HD5718.M39

ISBN 978-0-333-32753-1

ISBN 978-1-349-17477-5 (eBook)

DOI 10.1007/978-1-349-17477-5 


\section{Contents}

Acknowledgements vii

List of Tables and Figures viii

$\begin{array}{ll}\text { Introduction } & 1\end{array}$

1. Clerical and Administrative Work: The Background 7

Clerical work and clerical workers: 'proletarian' or otherwise? 7

The clerical workforce in Britain 16

Clerical work and clerical workers: 'proletarianisation' rejected

2. Clerical Work and the Impact of Automation 42

Introduction $\quad 42$

The case studies: levels of development 49

Clerical and administrative work described $\quad 57$

Perceptions of the work task 65

Computer staff 68

Conclusions $\quad 72$

3. The White-Collar Workforce: Men 78

Male mobility: career routes $\quad 80$

Existing careers and future possibilities $\quad 85$

Clerks with mixed work experience $\quad 93$

The extent of mobility $\quad 95$

Who gets promoted? 103

Attitudes to work, promotion and careers 112

$\begin{array}{ll}\text { Summary and conclusions } & 125\end{array}$

4. The Clerical Workforce: Women 129

Women in the class structure 129

Women and employment 135 


\section{vi Contents}

Women's work

Women as workers

Summary and conclusions

5. Trade Unionism

Introduction: interpretations of white-collar union growth

The organisations and their unions

Men and women, in and out of the unions

BIFU and the staff association

Attitudes to trade unionism

Conclusions

6. Conclusions

Introduction

Trade unions and the structuring of non-manual labour markets

The 'service class'

Lahour process, labour markets, and structural ambiguity

Men, women and the future

Notes and References

Bibliography

Index 


\section{Acknowledgements}

We are acutely conscious of the fact that, although only our names appear on the title page, this book could not have been written without the advice, encouragement and assistance given by many people. Our major debt is to the trade-union representatives, employees and managers at 'Cohall', 'Lifeco' and 'Southbank'. Considerations of anonymity make it impossible for us to acknowledge particular individuals, but we would like to take this opportunity to thank all those who gave so freely of their time during the period of our fieldwork, which was carried out as part of a project sponsored by the Social Science Research Council. Stuart Reid and Tim Snow also worked on the project, and we gratefully acknowledge their help and assistance. Steve Mosley gave invaluable assistance in data processing which frequently went well beyond the call of duty. Molly Allen typed and retyped questionnaires, reports and manuscripts with unfailing cheerfulness and accuracy. Bob Blackburn, Ken Prandy and Sandy Stewart gave much-needed encouragement and advice at the start of our research, and Jon Gubbay and Nick Abercrombie read and commented on the manuscript. Shirley, Gerald, Jenny and Anne will doubtless be relieved that the book has been completed, and to them, many thanks. 


\section{List of Tables and Figures}

\section{Tables}

1.1 Relative earnings, 1913-78

2.1 Work description (degree of control) by grade level

2.2 Work description compared with assessment of job interest, routine, and capacity for decision-making

3.1 Promotion with age: men only

3.2 The extent of promotion with age: men only

3.3 Highest qualification obtained before entering fulltime employment (men only)

3.4 Men aged 25-34: pre- and post-entry qualifications and grade level

3.5 Attitudes to promotion by age: summary table (men only)

3.6 Do you feel that there are any internal barriers or limits on promotion ...?

4.1 Would you be prepared to move if you were offered a better job?

4.2 Work description and grade level by gender

4.3 Interest in gaining promotion; women in 'primary' and 'secondary' jobs

4.4 Interest in gaining promotion by age and life cycle stage (women only)

4.5 Reasons given for interest, or lack of interest, in gaining promotion by age and life cycle stage (women only)

5.1 Manual and white-collar union membership and density in Great Britain: selected years 1911-79 168

5.2 Levels of trade-union membership in Cohall, Lifeco and Southbank: men and women

5.3 Union membership and social origins: men and women 187 
List of Tables and Figures ix

5.4 Attitudes to work and promotion among women unionists and non-unionists at Lifeco and Southbank 193

5.5 BIFU and staff association membership by grade level: men only

\section{Figure}

3.1 Age distribution of males: comparing clerks and the total population 